\title{
VISIT TO THE ESSEX MUSEUM OF NATURAL HISTORY, ROMFORD ROAD, STRATFORD, ESSEX.
}

MARCH I 7 TH, 1906.

Director: W. CoLE, F.L.S., F.E.S.

Excursion Secretary: Thos. W. REAdER, F.G.S.

(Report by WM. COLE aND T. W. READER.)

THE party, numbering twenty-eight, was welcomed by Mr. Cole in the Library, where he gave a few words of explanation of the purpose and methods of the Museum. It is the outgrowth of the Essex Field Club's Museum, which was founded with the intention of gathering a collection of specimens to illustrate the natural history, geology, and prehistoric archæology of the county of Essex ; but it would be obvious to the visitors that the pretty building so handsomely fitted up with cases and cabinets would be beyond the ability of a local society to provide. The Museum, as it at present exists, is the result of the enlightened policy of the borough of West Ham, aided by a generous donation of $£ 4,000$ from Mr. Passmore Edwards and by subscriptions from the members of the club. The upkeep of the Museum is controlled under an agreement included in the. West Ham Corporation Act, 1898, between the Corporation and the Essex Field Club, whereby the scientific management and the appointment of the Curator rests with the Club, while the care of the building as a public exhibition is in the hands of the Corporation."

The Director pointed out that the objects of the Museum were three : (1) Educational ; (2) the conservation of authentic sets of local (Essex) specimens; and (3) the encouragement of local observation and research. The possibility of fulfilling these three purposes was considered in a paper read at the South East Union of Natural History Societies in 1898, and the methods there indicated are being carried out in the Museum. The specimens publicly exhibited in the open cases are largely of an educational character, the longer sets of Essex specimens being placed in cabinets either open to the ordinary visitor or to be inspected on application to the Curator. The Educational specimens are of necessity restricted in number, and attempts are being made to illustrate principles rather than to tire the visitor by showing a multitude of objects.

\footnotetext{
*The "Idea" of the Museum works well practically, and this probably unique agreement should be studied by those interested in the establishment of local museums, Full particulars may be obtained from the E.F.C. Museum Handbook No. 3 , and the Year Book E.F.C. for 1905 .
} 
The attention of the members was particularly directed to three or four collections which indicated the methods which the Curator is endeavouring to pursue. In a small room a series of specimens illustrating the principles of Protective Resemblance, Mimicry, etc., amongst insects were shown.

The collection of Mollusca was alluded to as an example of the plan to be eventually carried out in all the groups of the Invertebrata. First a small typical series of shells from all parts of the world is shown to familiarise the visitor with the group and to give an idea of classification; then a series to demonstrate the salient points of the external and internal anatomy of the Mollusca; thirdly, a set of the Essex species in cabinets, and fourthly, a case containing a series of the Cephalopoda arranged to show their geological history, and survival of the group to the present day.

Other special series shown were the " History of the Horse : a Lesson in Evolution," and a case containing specimens indicating the form, structure, and development of the earliest allies of the vertebrata.

Attention was also called to a very beautiful series of British Hawks, illustrating the old Essex sport of Falconry, which had been preparet and presented to the Museum by Mr. J. E. Harting, F.L.S.

In the Archæological section of the Museum Mr. Cole called attention to the curious "Red Hills" so frequently found in the estuarine marshes of Essex, which seemed to be remains of ancient pottery works, and to the "Dene-holes" at Grays, which had occupied the Club's attention for some years. Although the problem of these pits could not be considered as finally solved, Mr. Cole said that in the opinion of Mr. T. V. Holmes and himself the probabilities of their being store pits for food and possibly for shelter in troublous times were very great. The remains from the Pile dwelling found by the Rev. J. W. Kenworthy at Skitt's Hill, near Braintree, and a collection of pottery, etc., from Norsey Wood presented by Dr. A. E. Salter, F.G.S., also formed interesting matters of discussion.

Ascending the staircase, the party were then conducted by Mr. Reader over the Geological section. One end of the gallery is devoted to the collection of Crag fossils made and presented by Mr. W. H. Daton, F.G.S., while at the opposite side are the Pleistocene remains from Ilford and the Lea Valley, the radial cases being devoted to the general series of fossils chiefly from the collections presented by Mr. Carvalho and Dr. Horace Brown, F.R.S., etc. The Rock collection, arranged by $\mathrm{Mr}$. Thos. W. Reader; was then explained, and received considerable attention, as so many of the specimens there shown were collected by him to illustrate the various points of interest during past excursions of the Geologists' Association. The series commences with the question, "What is a rock ?" the specimens 
shown being those found in the streets and ground round the Museum, such as the paving-stones and setts (bard) and sand and clay (soft). Then their use by primitive man, ancient and modern, as Palæoliths, which he made use of for various everyday purposes; flint and pyrites for obtaining fire, and modern stone adzes, still in use by the Islanders of the South Seas. Following this are a number of examples of rocks used by us for building, decoration, and various manufacturing and commercial purposes, followed by their formation in various ways by the agency of heat, water, animals, and plants. The next case is devoted to the composition of rocks, showing that they are built up of a number of minerals, and specimens of the chief rock-forming minerals were there exhibited. A number of interesting forms of structure, fracture, coherence, and colour are then shown. Next came a series illustrating the various changes undergone since deposition by breaking up processes, such as the action of ice, moving water, wind, and disengaged gases, earth movements, chemical action, heat, and the agency of organisms. After this introduction the general collection follows, in which are found examples of all the classes into which rocks are divided, the last case being devoted to a series of the vatious kinds of "road-metal" used in the borough of West Ham.

On the walls of the gallery are arranged a fine series of Essex prints kindly lent by Mr. J. Avery.

A vote of thanks was proposed by the President (Mr. Herries, M.A.), and the party then returned to town.

\section{VISIT TO THE MUSEUM OF Mr. G. E. DIBLEY AT LOWER SYDENHAM.}

\section{Saturday, March 24TH, Ig06.}

(Report by C. Davies SherboRn.)

Mr. DibLEX's collection, besides containing a general series, is notably rich in fossils from the Chalk, both Grey and White, although despoiled of many of its richest treasures, which have gone to fill gaps in the British Museum (Natural History).

Despite the weather thirty-two persons visited Sydenham, and were hospitably received by Mrs. Dibley.

So much interest has of late years been spent upon the Chalk, and so much progress in our knowledge of that deposit made, that the exhibition of so fine a series of zoned specimens was most instructive and interesting. They are nearly all 